\title{
NEGATIVE TONE AND READABILITY IN MANAGEMENT DISCUSSION AND ANALYSIS REPORTS: IMPACT ON THE COST OF DEBT
}

\author{
Eka Sari Ayuningtyas ${ }^{1}$, Iman Harymawan ${ }^{*}$ \\ 'Department of Accounting, Faculty of Economic and Business, Universitas Airlangga \\ Address: ' Jl. Airlangga No. 4 - 6, Airlangga, Gubeng, Surabaya, Jawa Timur, Indonesia 60115. \\ *E-mail: harymawan.iman@feb.unair.ac.id
}

\begin{abstract}
Companies use disclosure as a strategy to transfer and communicate selected information to stakeholders. This study examines the association between the firm's textual disclosure strategy and cost of debt by looking at the tone and readability of Management Discussion and Analysis (MDandA) reports and using a sample of 1596 Indonesian listed companies from all industries except the financial industry, from 2011 to 2018, and using ordinary least square (OLS) regression to test the research hypotheses. The findings suggest that both negative tone and poor readability level are associated positively with the cost of debt. This paper contributes to knowledge of the important aspects firms need to consider when setting their disclosure strategies, mainly how the tone and readability of firms' annual reports may be interpreted by users/creditors and affect the amount they will charge the firm for debt.
\end{abstract}

Keywords: Negative tones, readability, textual disclosure, cost of debt

JEL Classification: G31, G32, M40, M41

Article History:

Received: May 4, 2021; Revised : June 28, 2021; Accepted: August 9, 2021; Available Online : August 28, 2021 DOI: $10.20473 /$ imtt.v14i2.26681

\section{INTRODUCTION}

Stakeholders use companies' Annual reports to make their economic decisions. The way information is delivered in the annual report will affect the stakeholders' judgment about the performance of the companies. This implies a need for companies to use textual disclosure strategies. IASB has outlined plans to prioritize improvements to the effectiveness of annual report communications (Crump, 2016). The Securities and Exchange Commission has also taken action to improve the understandability of annual reports. "More disclosure does not always mean better disclosure. As public company regulatory filings with the SEC have become increasingly longer and less readable, so have concerns about the implications of poor communication". Bloomfield(2008) pointed out that managers are tempted to obfuscate their annual reports when a company has a poor performance by making the text more challenging to read. On the other hand, the reports become easier to read when the company has good performance. Poor communication can lead to negative economic consequences and harm the company's reputation, making communication effective and the readability of annual reports essential. 


\section{Eka Sari Ayuningtyas Iman Harymawan}

According to Rahman (2019), the Annual report contains both quantitative and textual information simultaneously. Many researchers already examined the effect of quantitative information on companies' economic outcomes. Persakis and latridis(2017), Ding et al.(2016), and Andrade et al.(2014)found that earnings quality is related negatively to the cost of debt. However, even though almost $80 \%$ of management disclosures were represented in narrative text, limited studies are investigating the impact of qualitative information. Bonsall and Miller(2017) identified why stakeholders consider that management's exposure and explanation of information are very important. Firstly, managerial opinions which diagnose a firm's future performance and plans, as found in the management discussion and analysis (MDandA) section, constitute important information that cannot be described in the form of numerical data. Secondly, in conveying information, text-based messages are relatively more elastic compared to numerical data.

The readability of annual reports is generally measured by indices concerned about the number of words, sentences, and complex words (Li, 2008; Ajina, Sougne and Lakhal, 2015; Lo, Ramos and Rogo, 2017; Luo, Li and Chen, 2018). Loughran and McDonald(2016)argue that these indices are insufficient to indicate whether annual report readability affects users' judgment and decision making. However, textual risk disclosures present the user with companies' assessments about future contingencies and a range of exposures to market factors. Their study shows a significant impact of risk disclosures on user's risk perceptions, i.e., the range of users' predictions of future performance. Given the above arguments and findings that highlight the importance of narrative disclosures, this study aimed to investigate the impact of textual information, in terms of tone and readability, on firms' economic consequences.

In particular, this study investigates the association between negative tone and readability of annual reports on creditor's decisions related to the cost of debt. Strategic disclosure theory and signalling theory suggest that a negative tone signals the disclosure of risk factors, increasing users' risk perceptions. In addition to that, less readable reports may indicate that management is obfuscating undesirable performance information. Loughran and McDonald(2016)found a significant impact of negative tone on the range of users' predictions of future performance. Thus, the result is expected to be negative tone, and poor readability in annual reports would lead to a relatively high cost of debt. A sample of 1596 firm-year observations from 4932 firms listed on the IDX year 2011-2018 was used in this study. Ordinary Least Square (OLS) analysis was used to determine the relationship between the negative tone and readability of annual reports and the cost of debt. The main finding of this study indicates that a strongly negative tone and poor readability in the annual report lead to increased cost of debt. 
Indonesia has a very interesting setting for this topic. Annual Reports of companies in Indonesia are regulated under Financial Service Authority regulation number 29 /POJK.04/2016. According to the regulation, annual reports not only serve as a format for the Board of Directors and Board of Commissioners to discharge their accountability in managing and supervising the company but are also one of the important sources of information for shareholders in making investment decisions and for monitoring (Annual Report of Public Firm). In this context, the readability and tone of the textual report also play a part in influencing the accuracy of the information. The annual report should be written in two languages, Indonesian and a foreign language, mainly English. This rule facilitates all of the stakeholders, including foreign investors, access to the information. Therefore, researchers analyze the readability and the tone of MDandA, which is written in English.

Several cases of manipulating information in firm disclosures have occurred in Indonesia, e.g., certain large Indonesian companies have manipulated their debt information and earnings, respectively. Those cases show that big companies may have an incentive to be involved in data and information manipulation. The manipulation of financial data can be relatively easily detected, but it is not the case for textual data. There are no specific rules that regulate and standardize textual disclosure, especially in Indonesia. Moreover, language and word selection are very sensitive to misinterpretation, making textual disclosures, especially their readability and tone, become an interesting topic for discussion using the Indonesian firm context.

The first section of this paper introduces the main topic. A review of the literature and development of the research hypotheses are presented in the second section, followed by the research methodology and data collection in the third. The fourth section of the paper discusses the empirical results, and the last section concludes the study, discusses its limitations and suggests opportunities and avenues for future research.

\section{LITERATURE REVIEW AND HYPOTHESES}

\section{The Use of a Negative Tone in Annual Reports}

The tone is the sentiment of textual narratives in a corporate disclosure (Loughran and McDonald, 2011; Rahman, 2019). The use of negative tone or pessimistic words in annual reports might increase the levels of risk perceived by stakeholders leading to increased economic consequences faced by the firms. Kim et al.(2019) argue that corporate managers have incentives to maximize investors' perceptions of firm value as reflected in stock prices. Tetlock(2007) examined the link between the tone of the Wall Street Journal's "Abreast of the Market" daily column and stock market levels and found that high levels of journalistic pessimism in the daily column were associated with both low subsequent stock returns and 


\section{Eka Sari Ayuningtyas Iman Harymawan}

high subsequent stock market volatility. Loughran and McDonald(2013)also support the previous findings by showing that initial public offerings (IPO) which use more pessimistic or uncertain texts demonstrated higher first-day returns, subsequent volatility, and absolute offer price revisions. Besides, previous research by Abernathy et al.(2018)finds that firms with less readable footnotes associated with longer audit report lag have higher audit fees and are more likely to receive a modified going concern opinion. They also find that the readability of financial footnotes is associated with a higher possibility of financial misstatements and future accounting-related litigation.

Focusing on textual information in MDandA reports, previous studies have found that intensive use of negative tone is associated with low firm performance. Davis and Tama-Sweet(2012) found a significant relationship between tone in the MDandA section of the annual report and future return on assets (ROA). The more pessimistic the MDandA tone, the lower the subsequent ROA for the company. Lim et al.(2018) suggested that prospector companies with more words categorized as negative and uncertain tones have less readable MDandA reports. Ertugrul et al.(2017)found that firms with a less readable MDandA section in their 10-Ks report, a more uncertain ambiguous tone, experienced relatively high external financing costs and displayed more managerial information hoarding, resulting in a higher stock price crash risk.

Firms can decide the type and amount of information they want to disclose. Strategic disclosure theory suggests that firms can influence stakeholder perspectives by communicating the information in their annual report. The tone of the texts can also affect how stakeholders interpret the information. A positive tone may indicate that the companies are more optimistic about their performance, whilst a negative tone is more likely to be used when they are less confident about their performance. Using a more negative tone could mean a higher level of risk disclosure, including previously unknown risk factors and contingencies, leading to an increase in user risk perception. It is argued in this study that these high-risk perception users/creditors may increase the cost of debt to the firm. Therefore, the first hypothesis is:

\section{Hypothesis 1: The use of a more negative tone in the annual report leads to a higher cost of debt}

\section{Readability of Annual Report}

Readability is broadly defined as the ease with which content can be read and understood (Bhardwaj and Imam, 2019). Readability has become an essential dimension of the communication quality between the financial reporting providers and the readers (Courtis, 2004; Linsley and Lawrence, 2007; Tan, Wang and Zhou, 2015). Managers could intentionally reduce the readability of narrative accounting disclosures by making them more complex. This 
theory is called the management obfuscation hypothesis (de Souza et al., 2019). Firms tend to obfuscate their annual reports by making the texts more difficult to read when they have poor performance and easier to read when they have good performance. According to Courtis(2004), obfuscation is "a type of writing obscures the intended message". Many accounting literatures assumes that management's conscious attempt to obfuscate bad news results in less-readable annual reports (Jones and Shoemaker, 1994; Kabir, Li and VeldMerkoulova, 2013; Li, 2008).

Previous studies have found that annual reports are less readable when firms have performed poorly. The association between readability and performance can be examined by looking at a firm's earnings quality, earnings management, and earnings persistence (Li, 2008; Ajina, Sougne and Lakhal, 2015; Lo, Ramos and Rogo, 2017; Luo, Li and Chen, 2018). Researchers have also explored the economic consequences of readability, including its impact on firm value, cost of equity, and cost of debt. Hwang and Kim(2017) found that readability may affect firm value significantly. The investor's trust in the information disclosed by firms decreases when they have less readable annual reports. Dyer et al.(2016); Lee(2012); Miller(2010); Rennekamp(2012); and You and Zhang(2009) revealed that investors reacted adversely to less readable disclosure announcements, indicating that readability may affect capital market efficiency. Bonsall and Miller (2017) and Ertugrul et al.(2017) also found that firms with less readable annual reports have lower credit ratings, stricter loan contract terms, higher risks, and higher costs of debt capital. Accordingly, researchers argue that less readable annual reports may lead to a higher risk faced by the firms and the other stakeholders, especially in terms of its impact on their cost of debt.

In this study, firstly, researchers want to test the direct relationship between annual report readability and cost of debt by looking at firm interest expense. In line with the signalling theory, managers tend to hide bad information by making their reports less readable. Lenders may perceive this as a high-risk factor and a sign of uncertainty over future performance. Researchers argue that the higher (lower) the possible risk, the higher (lower) the cost that lenders or creditors will charge to the firm. Therefore, our first hypothesis is as follows:

Hypothesis 2: A firm with less (more) readable annual reports has a higher (lower) cost of debt.

\section{RESEARCH METHODS}

\section{Sample}

The research sample consists of 1596 non-financial public companies listed in the Indonesian stock exchange from 2011 to 2018. Financial companies are excluded in this study because they have a different nature of financial reporting. Researchers obtained the Management Discussion and Analysis (MDandA) data by hand-collecting from the IDX website 


\section{Eka Sari Ayuningtyas Iman Harymawan}

(www.idx.co.id): the official disclosure website of listed companies in Indonesia. The data was then converted from pdf format to txt format. Researchers input the data in notepad format (.txt) to the application named "readability.exe" to measure the readability score of each MDandA report. Researchers obtain the tone data using text mining and sentiment analysis techniques(Kravet and Muslu, 2013; Liebmann, Orlov and Neumann, 2016; Loughran and McDonald, 2011). Researchers collect the financial data through the OSIRIS database. All the data were combined using STATA.

\section{Measurement of Variables \\ Dependent Variable}

The dependent variable, Cost of Debt (COD), is measured by dividing the firm's interest expense by its average short-term and long-term debt during the year. Interest expenses are disclosed in the income statement section, and short-term and long-term debts are disclosed in the balance sheets section of firms' financial statements.

\section{Independent Variable}

Two independent variables will be tested in this research. They are Negative Tone (NTONE) and Readability Level, which are measured using four readability indexes. Researchers use the Management Discussion and Analysis (MDandA) section of annual reports. This section is required by law and as a medium where managers have discretion over how to explain the company's business, financial conditions, and results of operation (Lo, Ramos and Rogo, 2017). Loughran and McDonald (2016) proposed a measure of textual disclosure from the context point of view. The context is measured by how much negative tone is used in a text.

Those negative tones might indicate some possible risk of firm performance. Related to that findings, Kravet and Muslu(2013) find that firm's disclosures affect investors' risk perceptions and market measure of risk, information asymmetry and firm value. Furthermore, Bonsall and Miller(2017) examine the impact of narrative disclosure readability on bond ratings and the cost of debt capital. In this research, researchers follow Kravet and Muslu(2013) 's approach, which was also used by Bonsall and Miller(2017)and to recognize and control the proportion of terms used in statements containing risk by looking at how much negative tone used in the text (NTONE). NTONE is defined as the existence of risk sentences with a negative tone. First, the sentences are categorized into risk sentences, and then those risk sentences are selected again and categorized as risk disclosure if they contain a negative tone. The number of negative tones from selected risk sentences will be used as variables.

As noted by DuBay(2007), the readability definition offered by Klare(1963) - "the ease of understanding or comprehension due to the style of writing"-tends to focus on writing style 


\section{Jurnal Manajemen Teori dan Terapan \\ Volume 14. No. 2, Agustus 2021}

versus content, coherence, and organization. Readability is about how easily the reader can understand the disclosure of information in a narrative text. Researchers measure the readability level of a text-based on the length of sentences and the words used. The longer the sentences, the more complex and unusual the word will result in a higher level of readability, or the harder the text can be understood. There are four indices researchers use in this research to measure the readability of MDandA. They are Flesch-Kincaid Readability Index (FKR) and Flesch-Kincaid Grade Level (FKG) by Flesch(1943), Gunning Fog Index (GF) by Gunning(1952), and Coleman-Liau Index (CL) by Coleman and Liau(1975). The formula of those indices are as follows:

$$
\begin{gathered}
C L=5,89 \times\left(\frac{\text { characters }}{\text { words }}\right)-29,5\left(\frac{\text { sentences }}{\text { words }}\right)-15,8 \\
F K R=-1\left(206,835-1,015 \times\left(\frac{\text { total words }}{\text { total sentences }}\right)+84,6\left(\frac{\text { total syllables }}{\text { total words }}\right)\right) \\
F K G=0,39 \times\left(\frac{\text { words }}{\text { sentences }}\right)+11,8\left(\frac{\text { syllables }}{\text { words }}\right)-15,59 \\
G F=0,4 \times\left\{\left(\frac{\text { word }}{\text { sentences }}\right)-100\left(\frac{\text { complex words }}{\text { words }}\right)\right\}
\end{gathered}
$$

All of those four indices are commonly used by scholars to score the readability of narrative text. They use several sentences, words and complex (multisyllabic) words used in a text to measure the level of readability. So if the longer the sentences, the more words and complex words used, the more difficult the text to be understood, means the less readable it is. Complex or multisyllabic words are referring to words that have more than two syllables. The readability

\begin{tabular}{|c|c|c|}
\hline Score & School-level & Notes \\
\hline 100.00-90.00 & 5th grade & $\begin{array}{l}\text { Very easy to read. Easily understood by an average } \\
11 \text {-year-old student. }\end{array}$ \\
\hline $90.0-80.0$ & 6th grade & Easy to read. Conversational English for consumers. \\
\hline $80.0-70.0$ & 7th grade & Fairly easy to read. \\
\hline $70.0-60.0$ & 8th and 9th grade & $\begin{array}{l}\text { Plain English. Easily understood by } 13 \text { - to } 15 \text {-year-old } \\
\text { students. }\end{array}$ \\
\hline $60.0-50.0$ & $\begin{array}{l}\text { 10th to } 12 \text { th } \\
\text { grade }\end{array}$ & Fairly difficult to read. \\
\hline $50.0-30.0$ & College & Difficult to read. \\
\hline $30.0-0.0$ & College graduate & $\begin{array}{l}\text { Very difficult to read. Best understood by university } \\
\text { graduates. }\end{array}$ \\
\hline
\end{tabular}
score interpretation followed J K Courtis(1986) and is explained in table 1.

\section{Table 1.}

Readability Score 


\section{Eka Sari Ayuningtyas Iman Harymawan}

Table 1 explains that the higher the readability score, the more difficult the text is to be understood. Only specific persons with higher educational levels of bachelor, master, or doctorate degrees can understand. A less readable annual report requires users to devote more time to understand and extract the relevant information and impending interpretation of filings (Bloomfield, 2008). Poor readability can be derived from poor communication skills of management itself, or it is deliberately from management obfuscate to hide their poor performance (Li, 2008). The less readable filings result in higher uncertainty means the company should pay a higher risk perceived by the creditors and the higher cost of debt.

\section{Control Variable}

Based on prior cost of debt studies (Qiu and Yu, 2009; Valta, 2012; Bliss and Gul, 2012; FangKlingler, 2019; Kabir, Li and Veld-Merkoulova, 2013; Luo, Li and Chen, 2018), the following variables are included in the regression as control variables: firm size (SIZE), Leverage (LEV), Firm age or the number of years since incorporation (AGE), corporate governance (CG), and Firm Performance (ROA). Firm size is expected to be negatively associated with the cost of debt. Larger firms are more likely to have a lower cost of debt as they are perceived as less risky because they have more assets and greater opportunities for economies of scale. Leverage is expected to be positively related to the cost of debt because more highly geared firms are more likely to be considered risky by creditors.

According to the reputation effect posited by Diamond (1989), firms can create good credit histories over time, reducing the perceived risk to creditors. Therefore, firm age will be negatively associated with the cost of debt. Corporate governance is recognized by measuring the size of commissioners, directors, and independent commissioners. The higher the number means better control and lower risk. Firms with good corporate governance can enjoy lower interest rates. There is an exception for independent boards. Bradley and Chen(2015)document that independent directors set corporate policies that increase firm risk. Therefore, a larger size of independent directors might increase the cost of debt. Furthermore, the last is the firm performance which uses return on assets as the proxy.

\section{Regression Model}

The regression models used to test the hypotheses is:

$$
\begin{aligned}
C O D_{\mathrm{i}, \mathrm{t}}= & \beta_{0}+\beta_{1} N T O N E_{\mathrm{i}, \mathrm{t}}+\beta_{2} \text { READABILITY }_{\mathrm{i}, \mathrm{t}}+\beta_{3} C G_{\mathrm{i}, \mathrm{t}}+\beta_{4} S I Z E_{\mathrm{i}, \mathrm{t}}+\beta_{5} F A G E_{\mathrm{i}, \mathrm{t}}+\beta_{6} L E V_{\mathrm{i}, \mathrm{t}}+\beta_{7} R O A_{\mathrm{i}, \mathrm{t}}+ \\
& \beta_{8} I F E_{\mathrm{i}, \mathrm{t}}+\beta_{9} Y F E_{\mathrm{i}, \mathrm{t}}+e
\end{aligned}
$$

Description:

$\begin{array}{ll}\text { COD } & =\text { Cost of debt } \\ \beta O & =\text { Constant }\end{array}$ 


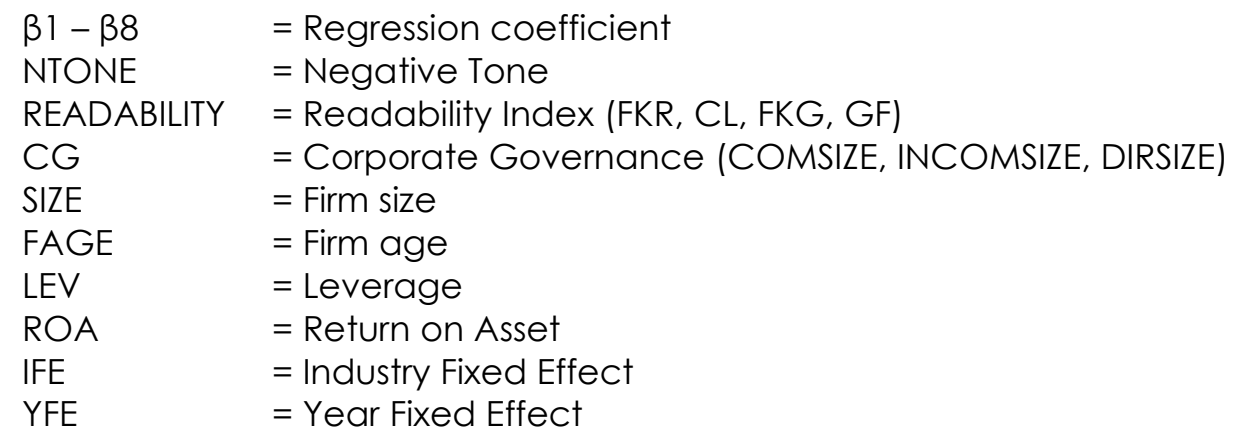

\section{RESULTS AND DISCUSSION}

\section{Descriptive Statistics}

The sample distribution based on industry type is presented in Table 2 and the year in Table 3. The descriptive statistics for both dependent and independent variables are provided in Table 4.

Table 2.

Sample Distribution Based on SIC

\begin{tabular}{ccc}
\hline SIC & Number of firms & Percentage \\
\hline 0 & 61 & $3.82 \%$ \\
1 & 256 & $16.04 \%$ \\
2 & 456 & $28.57 \%$ \\
3 & 270 & $16.92 \%$ \\
4 & 262 & $16.42 \%$ \\
5 & 132 & $8.27 \%$ \\
7 & 131 & $8.21 \%$ \\
8 & 28 & $1.75 \%$ \\
Total & 1,596 & $100 \%$ \\
\hline
\end{tabular}

The largest samples are from the manufacturing industry and are included in Standard Industrial Classification (SIC 2 code). This is because manufacturers are the largest contributor to Indonesia's economic growth. The mean value of the cost of debt is 0.038 (see table 4). This amount is closer to the minimum value rather than the maximum, indicating that most firms have a low cost of debt.

Table 3.

Sample Distribution Based on Period

\begin{tabular}{ccc}
\hline Year & Number of firms & Percentage \\
\hline 2011 & 108 & $6.77 \%$ \\
2012 & 151 & $9.46 \%$ \\
2013 & 182 & $11.40 \%$ \\
2014 & 165 & $10.34 \%$ \\
2015 & 262 & $16.42 \%$ \\
2016 & 250 & $15.66 \%$ \\
2017 & 265 & $16.60 \%$ \\
2018 & 213 & $13.35 \%$ \\
Total & 1,596 & $100 \%$ \\
\hline
\end{tabular}




\section{Eka Sari Ayuningtyas Iman Harymawan}

Table 4 shows that the gap between the minimum and maximum use of negative tone is very high, zero and 440 respectively. The mean value of the four readability indexes used in this study shows that companies tend to present less readable annual reports: a result that suggests they may be understood easily only by people with higher educational qualifications (bachelor's degree and above). Interestingly, one of the indices, namely the Flesch-Kincaid Readability Index, shows a negative minimum value. The use of very complex sentences causes this negative value whilst the size of the page is relatively small. Most companies have two or more commissioners, independent commissioners, and directors. Only one company has no independent commissioner. The details are presented in appendix attachment 1. The mean values of firm size and firm age are 28.689 and 31 , respectively. The mean of leverage is 0.547 , which indicates that the proportion of liability is higher than that of equity. The minimum firm value is negative 86.920, which means that some firms included in the sample are experiencing a loss or a negative income. Lastly, the mean of return on asset is 4.470 percent, which means average sample companies have a positive income.

Table 4.

Research Variable Descriptive Statistic $(N=1596)$

\begin{tabular}{lllll}
\hline & Mean & Median & Minimum & Maximum \\
\hline COD & 0.038 & 0.034 & 0.000 & 0.372 \\
NTONE & 37.456 & 34.000 & 0.000 & 440.000 \\
CLI & 23.457 & 23.396 & 15.799 & 46.415 \\
FKR & 25.838 & 26.125 & -34.270 & 97.020 \\
FKG & 21.858 & 21.927 & 13.041 & 38.770 \\
GF & 25.585 & 25.649 & 13.530 & 33.487 \\
COMSIZE & 4.432 & 4.000 & 2.000 & 22.000 \\
INCOMSIZE & 1.722 & 2.000 & 0.000 & 7.000 \\
DIRSIZE & 4.994 & 5.000 & 2.000 & 16.000 \\
SIZE & 28.689 & 28.704 & 22.658 & 33.320 \\
AGE & 31.058 & 29.000 & 2.000 & 116.000 \\
LEV & 0.547 & 0.505 & 0.000 & 9.674 \\
ROA & 4.470 & 3.620 & -86.920 & 59.740 \\
\hline
\end{tabular}




\section{Pearson Correlations}

The Pearson Correlation Model presented in Table 5 shows that the correlation between the NTONE and COD variables is significant at $p<0.05$.

There are no significant correlations between the readability index variables (CLI, FKR, FKG, and GF) and the COD variable.

Table 5.

Pearson Correlation Model $(N=1596)$

\begin{tabular}{|c|c|c|c|c|c|c|c|c|c|c|c|c|c|}
\hline & COD & NTONE & $\mathrm{CLI}$ & FKR & FKG & GF & COMSIZE & INCOMSIZE & DIRSIZE & SIZE & FAGE & LEV & ROA \\
\hline COD & 1.000 & & & & & & & & & & & & \\
\hline NTONE & $\begin{array}{l}0.058^{* *} \\
(0.020)\end{array}$ & 1.000 & & & & & & & & & & & \\
\hline CLI & $\begin{array}{l}0.055^{*} \\
(0.028)\end{array}$ & $\begin{array}{l}-0.009 \\
(0.726)\end{array}$ & 1.000 & & & & & & & & & & \\
\hline FKR & $\begin{array}{c}0.039 \\
(0.120)\end{array}$ & $\begin{array}{l}0.068^{* * *} \\
(0.007)\end{array}$ & $\begin{array}{l}0.488^{* * *} \\
(0.000)\end{array}$ & 1.000 & & & & & & & & & \\
\hline FKG & $\begin{array}{c}0.017 \\
(0.485)\end{array}$ & $\begin{array}{l}0.124^{* * *} \\
(0.000)\end{array}$ & $\begin{array}{l}0.409^{* * *} \\
(0.000)\end{array}$ & $\begin{array}{l}0.664^{* * *} \\
(0.000)\end{array}$ & 1.000 & & & & & & & & \\
\hline GF & $\begin{array}{c}0.018 \\
(0.467)\end{array}$ & $\begin{array}{l}0.094^{* * *} \\
(0.000)\end{array}$ & $\begin{array}{l}0.448^{* * *} \\
(0.000)\end{array}$ & $\begin{array}{l}0.676^{* * *} \\
(0.000)\end{array}$ & $\begin{array}{l}0.960^{* * *} \\
(0.000)\end{array}$ & 1.000 & & & & & & & \\
\hline COMSIZE & $\begin{array}{c}-0.113^{* * *} \\
(0.000)\end{array}$ & $\begin{array}{l}0.219^{* * *} \\
(0.000)\end{array}$ & $\begin{array}{c}-0.004 \\
(0.861)\end{array}$ & $\begin{array}{l}0.059^{* *} \\
(0.019)\end{array}$ & $\begin{array}{l}0.149^{* * *} \\
(0.000)\end{array}$ & $\begin{array}{l}0.115^{* * *} \\
(0.000)\end{array}$ & 1.000 & & & & & & \\
\hline INCOMSIZE & $\begin{array}{c}-0.055^{* *} \\
(0.028)\end{array}$ & $\begin{array}{l}0.172^{* * *} \\
(0.000)\end{array}$ & $\begin{array}{l}-0.001 \\
(0.970)\end{array}$ & $\begin{array}{l}0.063^{* *} \\
(0.012)\end{array}$ & $\begin{array}{l}0.167^{* * *} \\
(0.000)\end{array}$ & $\begin{array}{l}0.133^{* * *} \\
(0.000)\end{array}$ & $\begin{array}{l}0.798^{* * *} \\
(0.000)\end{array}$ & 1.000 & & & & & \\
\hline DIRSIZE & $\begin{array}{c}-0.139^{* * *} \\
(0.000)\end{array}$ & $\begin{array}{l}0.144^{* * *} \\
(0.000)\end{array}$ & $\begin{array}{l}-0.002 \\
(0.950)\end{array}$ & $\begin{array}{l}0.052^{* *} \\
(0.037)\end{array}$ & $\begin{array}{l}0.127^{* * *} \\
(0.000)\end{array}$ & $\begin{array}{l}0.101^{* * *} \\
(0.000)\end{array}$ & $\begin{array}{l}0.479^{* * *} \\
(0.000)\end{array}$ & $\begin{array}{l}0.426^{* * *} \\
(0.000)\end{array}$ & 1.000 & & & & \\
\hline SIZE & $\begin{array}{l}-0.040 \\
(0.113)\end{array}$ & $\begin{array}{l}0.356^{* * *} \\
(0.000)\end{array}$ & $\begin{array}{c}0.017 \\
(0.485)\end{array}$ & $\begin{array}{l}0.076^{* * *} \\
(0.002)\end{array}$ & $\begin{array}{l}0.194^{* * *} \\
(0.000)\end{array}$ & $\begin{array}{l}0.151^{* * *} \\
(0.000)\end{array}$ & $\begin{array}{l}0.539^{* * *} \\
(0.000)\end{array}$ & $\begin{array}{l}0.505^{* * *} \\
(0.000)\end{array}$ & $\begin{array}{l}0.541^{* * *} \\
(0.000)\end{array}$ & 1.000 & & & \\
\hline FAGE & $\begin{array}{c}-0.230^{* * *} \\
(0.000)\end{array}$ & $\begin{array}{c}0.034 \\
(0.180)\end{array}$ & $\begin{array}{l}-0.036 \\
(0.156)\end{array}$ & $\begin{array}{l}-0.039 \\
(0.124)\end{array}$ & $\begin{array}{l}-0.037 \\
(0.141)\end{array}$ & $\begin{array}{c}-0.055^{* *} \\
(0.027)\end{array}$ & $\begin{array}{l}0.206^{* * *} \\
(0.000)\end{array}$ & $\begin{array}{l}0.187^{* * *} \\
(0.000)\end{array}$ & $\begin{array}{l}0.130^{* * *} \\
(0.000)\end{array}$ & $\begin{array}{l}0.059^{* *} \\
(0.018)\end{array}$ & 1.000 & & \\
\hline LEV & $\begin{array}{l}0.076^{* * *} \\
(0.002)\end{array}$ & $\begin{array}{l}-0.012 \\
(0.623)\end{array}$ & $\begin{array}{c}-0.086^{* * *} \\
(0.001)\end{array}$ & $\begin{array}{c}-0.079^{* * *} \\
(0.002)\end{array}$ & $\begin{array}{c}-0.093^{* * *} \\
(0.000)\end{array}$ & $\begin{array}{c}-0.107^{* * *} \\
(0.000)\end{array}$ & $\begin{array}{l}-0.044^{*} \\
(0.080)\end{array}$ & $\begin{array}{l}-0.024 \\
(0.337)\end{array}$ & $\begin{array}{l}-0.054^{* *} \\
(0.031)\end{array}$ & $\begin{array}{l}-0.046^{*} \\
(0.064)\end{array}$ & $\begin{array}{l}0.071^{* * *} \\
(0.005)\end{array}$ & 1.000 & \\
\hline ROA & $\begin{array}{c}-0.159^{* * *} \\
(0.000)\end{array}$ & $\begin{array}{c}0.008 \\
(0.747) \\
\end{array}$ & $\begin{array}{c}0.043^{*} \\
(0.082) \\
\end{array}$ & $\begin{array}{c}0.048^{*} \\
(0.058) \\
\end{array}$ & $\begin{array}{l}0.060^{* *} \\
(0.017) \\
\end{array}$ & $\begin{array}{l}0.067^{* * *} \\
(0.008) \\
\end{array}$ & $\begin{array}{l}0.138^{* * *} \\
(0.000)\end{array}$ & $\begin{array}{l}0.130^{* * *} \\
(0.000)\end{array}$ & $\begin{array}{l}0.152^{* * *} \\
(0.000)\end{array}$ & $\begin{array}{l}0.118^{* * *} \\
(0.000)\end{array}$ & $\begin{array}{l}0.085^{* * *} \\
(0.001)\end{array}$ & $\begin{array}{c}-0.126^{* * *} \\
(0.000)\end{array}$ & 1.000 \\
\hline
\end{tabular}




\section{Eka Sari Ayuningtyas Iman Harymawan}

\section{Research Results}

The regression results shown in Table 6 indicate the positive association between negative tone and readability of annual reports and cost of debt. A negative tone is associated with the cost of debt with a coefficient value of 0.000 (t-value 3.21 ) and a significance level of $0.01 \%$. The coefficient value is zero because the number was very small before being rounded up to four decimals.

Table 6.

OLS Regression Result ( $N=1596)$

\begin{tabular}{|c|c|c|c|c|c|}
\hline \multirow[t]{2}{*}{ Variable } & \multirow{2}{*}{$\begin{array}{l}\text { Predicted } \\
\text { Sign }\end{array}$} & \multicolumn{4}{|c|}{ COD } \\
\hline & & (1) & (2) & (3) & (4) \\
\hline NTONE & + & $\begin{array}{c}0.000^{* * *} \\
(3.21)\end{array}$ & $\begin{array}{c}0.000^{* * *} \\
(3.10)\end{array}$ & $\begin{array}{l}0.000^{* * *} \\
(3.11)\end{array}$ & $\begin{array}{c}0.000^{* * *} \\
(3.13)\end{array}$ \\
\hline CLI & + & $\begin{array}{l}0.001^{* *} \\
(2.45)\end{array}$ & & & \\
\hline FKR & + & & $\begin{array}{l}0.000^{*} \\
(1.66)\end{array}$ & & \\
\hline FKG & + & & & $\begin{array}{l}0.000 \\
(0.65)\end{array}$ & \\
\hline GF & + & & & & $\begin{array}{l}0.000 \\
(0.74)\end{array}$ \\
\hline COMSIZE & - & $\begin{array}{c}-0.002^{* * *} \\
(-3.42)\end{array}$ & $\begin{array}{c}-0.002^{* * *} \\
(-3.45)\end{array}$ & $\begin{array}{c}-0.002^{* * *} \\
(-3.44)\end{array}$ & $\begin{array}{c}-0.002^{* * *} \\
(-3.44)\end{array}$ \\
\hline DIRSIZE & - & $\begin{array}{c}-0.002^{* * *} \\
(-3.57)\end{array}$ & $\begin{array}{c}-0.002^{* * *} \\
(-3.59)\end{array}$ & $\begin{array}{c}-0.002^{* * *} \\
(-3.58)\end{array}$ & $\begin{array}{c}-0.002^{* * *} \\
(-3.58)\end{array}$ \\
\hline INCOMSIZE & - & $\begin{array}{c}0.004^{* * *} \\
(2.88)\end{array}$ & $\begin{array}{l}0.004^{* * *} \\
(2.87)\end{array}$ & $\begin{array}{l}0.004^{* * *} \\
(2.85)\end{array}$ & $\begin{array}{c}0.004^{* * *} \\
(2.85)\end{array}$ \\
\hline SIZE & - & $\begin{array}{l}0.000 \\
(0.45)\end{array}$ & $\begin{array}{l}0.000 \\
(0.46)\end{array}$ & $\begin{array}{l}0.000 \\
(0.44)\end{array}$ & $\begin{array}{l}0.000 \\
(0.45)\end{array}$ \\
\hline LEV & + & $\begin{array}{l}0.003^{*} \\
(1.90)\end{array}$ & $\begin{array}{l}0.003^{*} \\
(1.86)\end{array}$ & $\begin{array}{l}0.003^{*} \\
(1.80)\end{array}$ & $\begin{array}{l}0.003^{*} \\
(1.82)\end{array}$ \\
\hline ROA & - & $\begin{array}{c}-0.000^{* * *} \\
(-3.77)\end{array}$ & $\begin{array}{c}-0.000^{* * *} \\
(-3.71)\end{array}$ & $\begin{array}{c}-0.000^{* * *} \\
(-3.67)\end{array}$ & $\begin{array}{c}-0.000^{* * *} \\
(-3.68)\end{array}$ \\
\hline AGE & - & $\begin{array}{c}-0.000^{* * *} \\
(-5.05)\end{array}$ & $\begin{array}{c}-0.000^{* * *} \\
(-5.07)\end{array}$ & $\begin{array}{c}-0.000^{* * *} \\
(-5.07)\end{array}$ & $\begin{array}{c}-0.000^{* * *} \\
(-5.07)\end{array}$ \\
\hline _cons & $?$ & $\begin{array}{l}0.039^{*} \\
(1.90)\end{array}$ & $\begin{array}{l}0.036^{*} \\
(1.66)\end{array}$ & $\begin{array}{l}0.035 \\
(1.53)\end{array}$ & $\begin{array}{l}0.009 \\
(0.38)\end{array}$ \\
\hline $\begin{array}{l}\text { Industry } \\
\text { Dummy }\end{array}$ & & Yes & Yes & Yes & Yes \\
\hline Year Dummy & & Yes & Yes & Yes & Yes \\
\hline r2 & & 0.110 & 0.109 & 0.109 & 0.112 \\
\hline N & & 1596 & 1596 & 1596 & 1596 \\
\hline
\end{tabular}

t statistics in parentheses

${ }^{*} p<0.1,{ }^{* *} p<0.05,{ }^{* * *} p<0.01$

The regression results shown in table 6 indicate that the Coleman-Liau and Flesch-Kincaid readability indices have positive and significant associations with the cost of debt, with coefficients of 0.001 ( $t$-value 2.45) and significance level $0.01 \%$ for the first index, and 0.000 ( $t$ value 1.66) and significance level $0.1 \%$ for the latter. The significant effect of the Coleman-Liau readability index means that a 1 point increase in the index would lead to a $0.001 \%$ increase in the cost of debt. This indicates that an increase in the less readable text presented in an 


\section{Jurnal Manajemen Teori dan Terapan \\ Volume 14. No. 2, Agustus 2021}

annual report will increase the cost of debt. The regression analysis for the other two indexes, namely the Flesch-Kincaid grade level and Gunning fog index, showed insignificant results.

The control variable: corporate governance; proxied by board size, including the numbers of commissioners and directors, are correlated to cost of debt negatively and significantly, with coefficient values of -0.002 ( $t$-value -3.42 ) and -0.002 ( $t$-value -3.57 ) respectively, and significance levels of $0.01 \%$ for both. These results align with previous findings (Li and Richie, 2016; Shailer and Wang, 2015; Kabir et al., 2016). The independent board size correlates positively with the cost of debt with a coefficient value of 0.004 ( $t$-value 2.88) and a significance level of $0.01 \%$. Firm size has a significantly positive relationship to the cost of debt with a constant of 0.000 ( $t$-value 0.45). This result is unexpected. The leverage variable has a positive and significant association with the cost of debt, with coefficient values 0.003 ( $t$-value 1.90 ) and a significance level of $0.1 \%$. ROA, a proxy for firm performance, and firm age have negative and significant impacts on the cost of debt with constant values of -0.000 ( $t$-value 3.77 ) and -0.000 (t-value -5.05), respectively, both at significance levels of $0.001 \%$.

\section{Discussion}

This study provides further evidence on the negative impact of the use of negative tone in annual reports. While a previous study conducted by Bonsall and Miller(2017)found that uncertain language or sentences containing negative tones are associated with more rating disagreement and wider credit spreads, our study found a significant relationship between negative tone and cost of debt. Among the important factors used by creditors to decide the cost of debt, they will charge by firm's risk level, which follows the general concept of "higher risk higher cost". Creditors could see the use of more negative tones by a company as a higher risk disclosure, a factor that has been found to significantly influence users' risk perceptions (Loughran and McDonald, 2016; Kravet and Muslu, 2013), and is then likely to affect their assessment of the company's cost of debt.

The cost of debt is an indicator that exposes the confidence level of creditors toward firms that manage their funds. Therefore, to minimize the cost of debt, companies tend to disclose more information to their creditors. However, managers may also disclose more information to obfuscate unfavourable information (i.e. bad performance) by providing a complex report text. The results of this support the findings of previous studies (Livingston and Zhou, 2010; Bonsall and Miller, 2017; Ertugrul et al., 2017)that provide evidence on the negative consequences of providing users/creditors with less readable annual reports. Mainly, our findings support our hypothesis that firms with less readable annual reports will have a relatively high cost of debt. This may be due to the higher risk perceived by the users/creditors affecting their decision about the company's cost of debt. 


\section{Eka Sari Ayuningtyas \\ Iman Harymawan}

Bonsall and Miller(2017)argued that firms with good corporate governance could enjoy lower interest rates. This argument has been supported by findings from previous studies (Li and Richie, 2016; Shailer and Wang, 2015; Kabir, Li and Veld-Merkoulova, 2013). This study shows that the number of commissioners and directors is related to the cost of debt negatively and significantly. Interestingly, while this negative relationship was expected, the number of independent directors is related positively and significantly to the cost of debt. The positive association between the number of independent directors and the cost of debt may indicate that independent directors set corporate policies that increase firm risk (Bradley and Chen, 2015).The independent directors may act in the interests of shareholders rather than bondholders, resulting in agency conflict between these two groups.

Leverage or debt ratio indicates the firm's ability to pay its debt using its assets. Bliss and Gul(2012)argue that more highly geared firms are more likely to be considered risky by creditors. The findings of this study support previous studies that found a positive relationship between leverage and cost of debt (Tee, 2018; Chakravarty and Rutherford, 2017; Bliss and Gul, 2012). It can be argued that companies with a good performance show lower levels of risk of bankruptcy and provide more assurance to the creditors about the company's capacity to pay its debt. This is in line with the reputational effect posited by Diamond(1989), that firms can create good credit histories that can reduce the perceived risk by creditors over time.

\section{CONCLUSION}

This research aims to test whether textual disclosure strategy, which was proxied by the use of negative tone and readability level, is associated with the cost of debt. This research uses 1596 samples of listed companies in Indonesia. The control variables examined in this study include corporate governance, firm size, firm age, and firm performance.

This study shows a positive and significant relationship between the use of negative tone and the cost of debt. More intensive use of negative tone or pessimistic words was associated with a higher cost of debt, and, thus, the first hypothesis is accepted. Two of the four readability indices used in this study have significant impacts and support the argument that less (more) readable annual reports will lead to higher (lower) costs of debt. Therefore, the second hypothesis is also accepted. In addition to that, two proxies for corporate governance (commissioner and director numbers) have negative associations with the cost of debt. The relationship between the number of independent board members and the cost of debt is also significant, but the direction is not as expected. The control variables associated significantly with the cost of debt include firm leverage, firm age and firm performance. 
There are several limitations of this study. Some companies published their annual reports in an image format; therefore, the text cannot be run in the readability.exe application. All of the readability indices used by researchers are based on the length of the sentence and the complexity of the wording. Future research in this area could use different proxies to measure the readability of annual reports, such as file size or page length, and consider some wellknown complex words/terms in the business area. Therefore, future studies may use different indices, such as the Bog Index, which includes a list of uncommon words to measure the readability of the text. This study omits the external environment conditions. Future studies could also examine the external environment factors that affect firms' disclosures, such as political, economic, social, technological and environmental factors, to enrich the research perspective.

The results of this study provide creditors with useful information they need to consider when deciding the amount of cost of debt they will charge to the firm. In particular, creditors can look at the use of negative tone and the readability of annual reports to evaluate the firms' disclosure quality and accuracy. The findings of this study will help management set a proper disclosure strategy by looking at the use of negative tone and readability of their annual reports in order to minimize their cost of debt

\section{REFERENCES}

Abernathy, J.L., Guo, F., Kubick, T.R. and Masli, A. 2018. Financial Statement Footnote Readability and Corporate Audit Outcomes. AUDITING: A Journal of Practice \& Theory, 38(2): 1-26.

Ajina, A., Sougne, D. and Lakhal, F. 2015. Corporate disclosures, information asymmetry and stock-market liquidity in France. Journal of Applied Business Research, 31 (4): 1223-1238.

Andrade, S.C., Bernile, G. and Hood, F.M. 2014. SOX, corporate transparency, and the cost of debt. Journal of Banking and Finance, 38(1): 145-165.

Annual Report of Public Firm.

Bhardwaj, A. and Imam, S. 2019. The tone and readability of the media during the financial crisis: Evidence from pre-IPO media coverage. International Review of Financial Analysis, 63: 40-48.

Bliss, M.A. and Gul, F.A. 2012. Political connection and cost of debt: Some Malaysian evidence. Journal of Banking and Finance, 36(5): 1520-1527.

Bloomfield, R. 2008. Discussion of 'Annual report readability, current earnings, and earnings persistence'. Journal of Accounting and Economics, 45(2-3): 248-252. 


\section{Eka Sari Ayuningtyas \\ Iman Harymawan}

Bonsall, S.B. and Miller, B.P. 2017. The impact of narrative disclosure readability on bond ratings and the cost of debt. Review of Accounting Studies, 22(2): 608-643.

Bradley, M. and Chen, D. 2015. Does board independence reduce the cost of debt? Financial Management, 44(1): 15-47.

Chakravarty, S. and Rutherford, L.G. 2017. Do busy directors influence the cost of debt? An examination through the lens of takeover vulnerability. Journal of Corporate Finance, 43: 429-443.

Coleman, M. and Liau, T.L. 1975. A computer readability formula designed for machine scoring. Journal of Applied Psychology, 60(2), p.283.

Courtis, J.K. 1986. An Investigation into Annual Report Readability and Corporate Risk-Return Relationships. Accounting and Business Research, 16(64): 285-294.

Courtis, J.K. 2004. Corporate report obfuscation: Artefact or phenomenon? British Accounting Review, 36(3): 291-312.

Crump, R. 2016. IASB chairman Hoogervorst to prioritise communication effectiveness of financial statements during second term. https://www.accountancyage.com/.

Davis, A.K. and Tama-Sweet, I. 2012. Managers' use of language across alternative disclosure outlets: Earnings press releases versus MD\&A. Contemporary Accounting Research, 29(3): 804-837.

Diamond, D.W. 1989. Reputation acquisition in debt markets. Journal of political Economy, 97(4): 828-862.

Ding, S., Liu, M. and Wu, Z. 2016. Financial Reporting Quality and External Debt Financing Constraints: The Case of Privately Held Firms. Abacus, 52(3): 351-373.

DuBay, W.H. 2007. Smart Language: Readers, Readability, and the Grading of Text. ERIC.

Dyer, T., Lang, M. and Stice-Lawrence, L. 2016. Do managers really guide through the fog? On the challenges in assessing the causes of voluntary disclosure. Journal of Accounting and Economics, 62(2-3): 270-276.

Ertugrul, M., Lei, J., Qiu, J. and Wan, C. 2017. Annual Report Readability, Tone Ambiguity, and the Cost of Borrowing. Journal of Financial and Quantitative Analysis, 52(2): 81 1-836.

Fang-Klingler, J. 2019. Impact of Readability on Corporate Bond Market. Journal of Risk and Financial Management, 12(4), p.184.

Flesch, R. 1943. Marks of readable style; a study in adult education. Teachers College Contributions to Education.

Gunning, R. 1952. Technique of clear writing. 
Hwang, B.-H. and Kim, H.H. 2017. It pays to write well. Journal of Financial Economics, 124(2): 373-394.

Jones, M.J. and Shoemaker, P.A. 1994. Accounting narratives: A review of empirical studies of content and readability. Journal of accounting literature, 13, p.142.

Kabir, R., Li, H. and Veld-Merkoulova, Y. V, 2013. Executive compensation and the cost of debt. Journal of banking \& finance, 37(8): 2893-2907.

Kim, C., Wang, K. and Zhang, L. 2019. Readability of 10-K reports and stock price crash risk. Contemporary accounting research, 36(2): 1184-1216.

Klare, G.R. 1963. Measurement of readability.

Kravet, T. and Muslu, V. 2013. Textual risk disclosures and investors' risk perceptions. Review of Accounting Studies, 18(4): 1088-1122.

Lee, Y. 2012. The effect of quarterly report readability on information efficiency of stock prices. Contemporary Accounting Research, 29(4): 1137-1170.

Li, F. 2008. Annual report readability, current earnings, and earnings persistence. Journal of Accounting and economics, 45(2-3): 221-247.

Li, S. and Richie, N. 2016. Income smoothing and the cost of debt. China Journal of Accounting Research, 9(3): 175-190.

Liebmann, M., Orlov, A.G. and Neumann, D. 2016. The tone of financial news and the perceptions of stock and CDS traders. International Review of Financial Analysis, 46: 159175.

Lim, E.K., Chalmers, K. and Hanlon, D. 2018. The influence of business strategy on annual report readability. Journal of Accounting and Public Policy, 37 (1): 65-81.

Linsley, P.M. and Lawrence, M.J. 2007. Risk reporting by the largest UK companies: readability and lack of obfuscation. Accounting, Auditing \& Accountability Journal.

Livingston, M. and Zhou, L. 2010. Split bond ratings and information opacity premiums. Financial Management, 39(2): 515-532.

Lo, K., Ramos, F. and Rogo, R. 2017. Earnings management and annual report readability. Journal of Accounting and Economics, 63(1): 1-25.

Loughran, T. and McDonald, B. 2011. When is a liability not a liability? Textual analysis, dictionaries, and 10-Ks. The Journal of finance, 66(1): 35-65.

Loughran, T. and McDonald, B. 2013. IPO first-day returns, offer price revisions, volatility, and form S-1 language. Journal of Financial Economics, 109 (2): 307-326.

Loughran, T. and McDonald, B. 2016. Textual analysis in accounting and finance: A survey. 


\section{Eka Sari Ayuningtyas \\ Iman Harymawan}

Journal of Accounting Research, 54(4): 1187-1230.

Luo, J., Li, X. and Chen, H. 2018. Annual report readability and corporate agency costs. China journal of accounting research, $11(3)$ : 187-212.

Miller, B.P. 2010. The effects of reporting complexity on small and large investor trading. The Accounting Review, 85(6): 2107-2143.

Persakis, A. and latridis, G.E. 2017. The joint effect of investor protection, IFRS and earnings quality on cost of capital: An international study. Journal of International Financial Markets, Institutions and Money, 46: 1-29.

Qiu, J. and YU, F. 2009. The market for corporate control and the cost of debt. Journal of Financial Economics, 93(3): 505-524.

Rahman, S. 2019. Discretionary tone, annual earnings and market returns: Evidence from UK Interim Management Statements. International Review of Financial Analysis, 65, p.101384.

Rennekamp, K. 2012. Processing fluency and investors' reactions to disclosure readability. Journal of Accounting Research, 50(5): 1319-1354.

Shailer, G. and Wang, K. 2015. Government ownership and the cost of debt for Chinese listed corporations. Emerging Markets Review, 22: 1-17.

de Souza, J.A.S., Rissatti, J.C., Rover, S. and Borba, J.A. 2019. The linguistic complexities of narrative accounting disclosure on financial statements: An analysis based on readability characteristics. Research in International Business and Finance, 48: 59-74.

Tan, H.-T., Wang, E.Y. and Zhou, B. 2015. How does readability influence investors' judgments? Consistency of benchmark performance matters. The Accounting Review, 90(1): 371-393.

Tee, C.M. 2018. Political connections, institutional monitoring and the cost of debt: evidence from Malaysian firms. International Journal of Managerial Finance.

Tetlock, P.C. 2007. Giving content to investor sentiment: The role of media in the stock market. The Journal of finance, 62(3): 1139-1168.

Valta, P. 2012. Competition and the cost of debt. Journal of Financial Economics, 105(3): 661682.

You, H. and Zhang, X. 2009. Financial reporting complexity and investor underreaction to $10-\mathrm{K}$ information. Review of Accounting studies, 14(4): 559-586. 